\title{
CLIMATE CHANGE IMPACTS AND ADAPTATION IN THE NEPALESE HIMALAYAS
}

\author{
Rijan Bhakta Kayastha \\ Kathmandu University, NEPAL
}

\begin{abstract}
The ongoing climatic changes and changes those are projected to occur in the near future are likely to have impacts on different sectors of Nepal. Impacts on water resources are likely to be more severe. Water resource sector ranks significantly higher than other sector because this sector is directly related to rising temperatures resulting in change in cryosphere; faster glacier melts and formation and expansion of glacial lakes and increased risk of Glacial Lake Outburst Flood (GLOF) events.

The longest instrumental records of maximum temperature of Kathmandu showed that air temperature was increasing rapidly in the recent past. The records from Kathmandu showed an increase in air temperature of $0.27{ }^{\circ} \mathrm{C}$ between 1897 and 1977 and of nearly $1{ }^{\circ} \mathrm{C}$ between 1975 and 1994. Such increase in air temperature is more rapid in the higher Himalayan regions inducing more melting of snow and glacier ice. The retreat rate of terminus of Glacier AX010 in the Shorong Himal was $2.7 \mathrm{~m} \mathrm{a}^{-1}$ from 1978 to 1989 and $16.7 \mathrm{~m} \mathrm{a}^{-1}$ from 1989 to 2004. The ongoing rapid retreat of glaciers is leading to formation of new glacial lakes and expansion of existing glacial lakes with increasing risk of GLOF events. The area of Tsho Rolpa Glacial Lake in Dolakha district was expanded to $1.452 \mathrm{~km}^{2}$ in August 2009 from 0.23 $\mathrm{km}^{2}$ in 1959. The expanding glacial lake is holding huge amount of water within the moraine dam among which considerable amount of water may be released suddenly if the dam breaks causing flood and debris flow with high chances of huge loss of life, infrastructure and biodiversity of the region and downstream. Therefore, more studies on glaciers and glacial lakes are very essential together with some preventive measures to reduce the risk of GLOF hazards in the Himalayas.
\end{abstract}

\section{KEYWORDS}

Climate change, Himalayas, glacier, glacial lakes, GLOF

\section{INTRODUCTION}

The ongoing climatic changes and changes those are projected to occur in the near future are likely to have impacts on water resources, agriculture, biodiversity, forest and socio-economic sectors of Nepal. Impacts on water resources are likely to be more severe. The vast water resources potential of Nepal has considerable importance in the economic development of the country. However, Nepalese river basins are spread over such diverse and extreme geographic and climatic conditions that the potential benefits of water are accompanied by risk. Besides,

https://doi.org/10.15626/Eco-Tech.2010.082 
climate change could add a new dimension to water management. Though the available surface water of Nepal $\left(202 \mathrm{~km}^{3}\right)$ could fulfill the demand of the country up to the end of $21^{\text {st }}$ century, the availability of only $26 \mathrm{~km}^{3}$ water in dry season shows that water scarcity is eminent in Nepal unless water resources are properly managed. With increasing surface temperatures, glacier melt is expected to increase, leading to increased summer flows in some river systems for a few decades, followed by a reduction in flows as the glaciers shrink over longer run. Besides, receding glaciers mean an increased risk of GLOF in the Himalayas.

Rainfall patterns are expected to undergo significant changes with global climate change. The monsoon rainfalls from June to September contribute more than $80 \%$ rainfall in Nepal, and constitute the principle sources of groundwater recharge. Utility of rainwater in general depends on its spatial and temporal distribution. Obviously, uniform precipitation over longer periods of time and larger areas of land is more useful, while highly erratic and concentrated rainfalls lead to high levels of surface runoff. With climate change, the inter-annual variability of monsoon is expected to increase further. Projections indicate more intense rainfall over shorter periods of time during monsoon, while dry spells are also expected to increase in frequency and intensity.

Another facet of climate change impacts on water availability for agriculture in Nepal is the expected increase in evaporation from soils and surface water reservoirs associated with rising temperatures. At the same time, water requirements of plants are expected to increase with rising temperatures. The present paper summarizes evidences of climate change impacts on the Nepalese glaciers, glacial lakes and some adaptation and mitigation measures which were taken in the recent past.

\section{VARIATION OF AIR TEMPERATURE}

Instrumental records of temperature between 1879-1977 are available from the Indian Embassy in Kathmandu (World Data Centre for Paleoclimatology, Boulder, USA: ftp://ftp.ncdc.noaa.gov/pub/data/paleo/treering/reconstructions/asia/nepal/kathmandu temp.txt). The temperature data prior to 1897 is not considered reliable [1], in part because of an abrupt temperature jump before 1893 and in part because there is data missing. [2] have summarized the data from four other stations in the Kathmandu Valley with records between 1971 and 1994 and derived a single composite Kathmandu temperature record from 1921 to 1994. This data set showed an increase in air temperature of $0.27^{\circ} \mathrm{C}$ between 1897 and 1977 (see Figure 1). This warming was very close to the suggested warming of $0.3{ }^{\circ} \mathrm{C}$ of the tropical atmosphere from the beginning of the century to the 1970 s by [3]. Major warming occurred after that period. [2] found that the Kathmandu temperature has increased by $1{ }^{\circ} \mathrm{C}$ for the period between 1975 and 1994. The authors have derived this value based on four different stations of the Kathmandu valley since the Kathmandu Indian Embassy ceased temperature recording in 1977. Therefore, the total warming in Kathmandu from 1897 to 1992 is about $1.25^{\circ} \mathrm{C}$. 


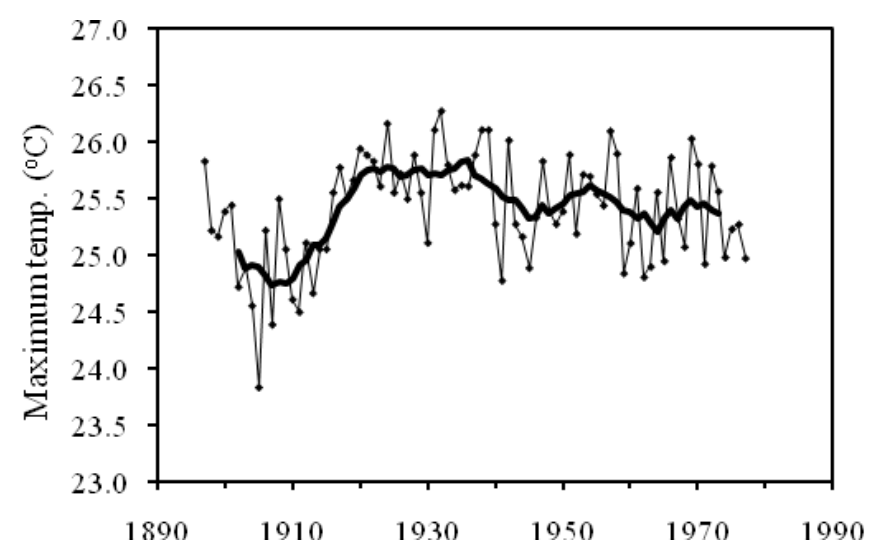

Figure 1. Annual mean maximum air temperature trend in the Kathmandu Indian Embassy (1897-1977). The 10 years running mean is shown with a thick line.

\section{IMPACTS ON GLACIERS}

There are 3252 glaciers in Nepal covering a total area of 5312 sq. km. [4]. Since glaciers are excellent indicators of climate change, the Nepalese glaciers provide good opportunity to study the impacts of global climate change in this region. Glacier study in a regular basis started in Nepal in early 1970s under the framework of Glaciological Expedition in Nepal (GEN) in collaboration between Nepal and Japan. Since then several glaciers in Hidden Valley of Dhaulagiri Region, Langtang Region, Shorong Himal, Khumbu Region and Kanchanjunga region have been studied. Some results of the glacier fluctuation studies are presented below.

The surface of Khumbu Glacier which is a large debris-covered valley glacier in the Khumbu Region, about $15 \mathrm{~km}$ long between Mt. Everest and Lohtse lowered by $10 \mathrm{~m}$ throughout the debris-covered ablation area in the period during 1978 to 1995 [5]. [6] reviewed terminus fluctuations of seven clean type glaciers in Khumbu region for the period 1970s-1989. Majority of glaciers have retreated in the range of 30 to $60 \mathrm{~m}$ in the observed period. An expedition organized in 2004 found the majority of glaciers in Khumbu Region continuing to shrink at a fast rate while some smaller glaciers have begun to disappear.

Glacier AX010 in the Shorong Himal $\left(27^{\circ} 42^{\prime} \mathrm{N}, 86^{\circ} 34^{\prime} \mathrm{E}\right)$ in the eastern part of Nepal is one of the most studied glaciers in Nepal. Changes in glacier terminus have been monitored since 1978 to 2008. The terminus retreat from 1978 to 1989 was $30 \mathrm{~m}\left(-2.7 \mathrm{~m} \mathrm{a}^{-1}\right)$, which is equivalent to $12 \mathrm{~m}$ thinning of the glacier surface. Similarly, the terminus retreat rates from 1989 to 1995,1996 to 1999 and 1999 to 2004 were $-6.7 \mathrm{~m} \mathrm{a}^{-1},-30 \mathrm{~m} \mathrm{a}^{-1}$ and $-14 \mathrm{~m} \mathrm{a}^{-1}$, respectively (see figure 2). 


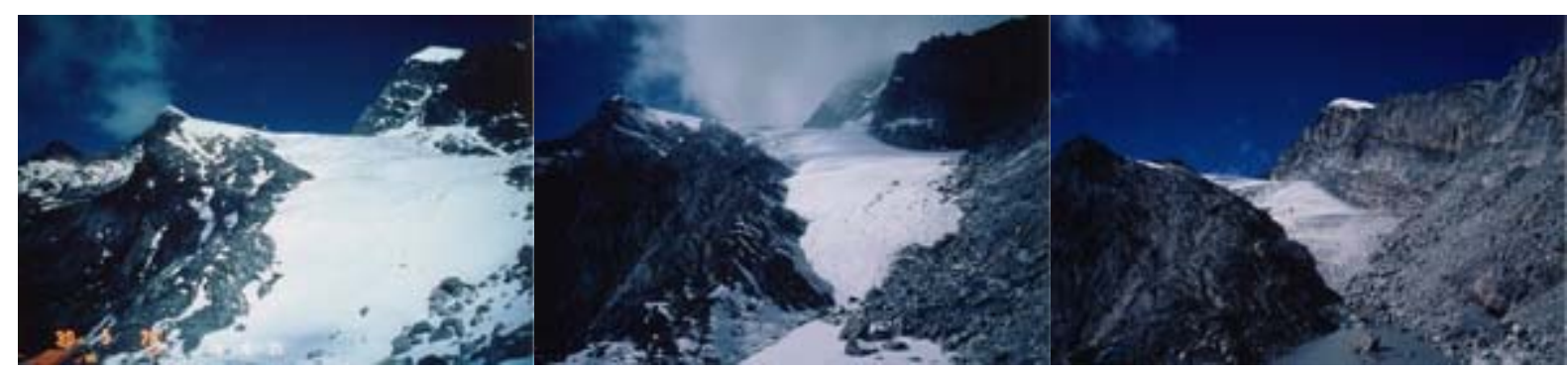

a) 1978

b) 1989

c) 1998

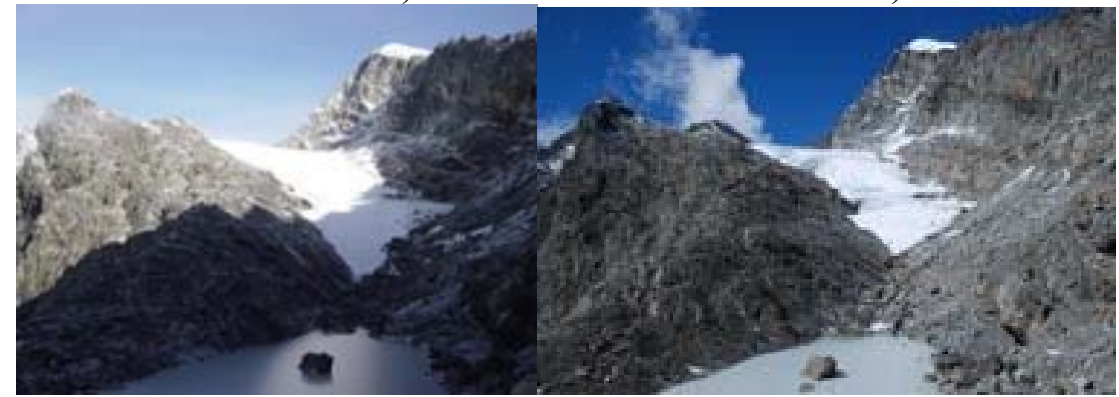

d) 2004

e) 2008

Figure 2. Glacier AX010 in the Shorong Himal since 1978 to 2008 (from www.cryoscience.net)

Yala glacier is the most studied glacier in Langtang Region in the central part of Nepal. The terminus of Yala Glacier in the Langtang Valley was retreated by 3 to $4 \mathrm{~m} \mathrm{a}^{-1}$ between 1987 and 1996. Similarly, Rikha Samba Glacier in the Hidden Valley in the western Nepal was retreated $10 \mathrm{~m} \mathrm{a}^{-1}$ between 1974 and 1994. Figure 3 shows location map of Glacier AX010, Yala Glaceir, Rikha Samba and Khumbu region.

[7] studied changes of the equilibrium line altitude (ELA) since the Little Ice Age (LIA) in the eastern Nepal. According to their study, the ELAs shifted up between the end of the LIA and 1992 and between 1959 and 1992 in eastern Nepal by 79 and 25 m, respectively. The limited number of climate records from Nepal, and analyses using a simple ELA-climate model, suggested that the higher rate of the shifting of the ELA between 1959 and 1992 was a result of increased warming that occurred after the 1970s at the higher altitudes in Nepal. 


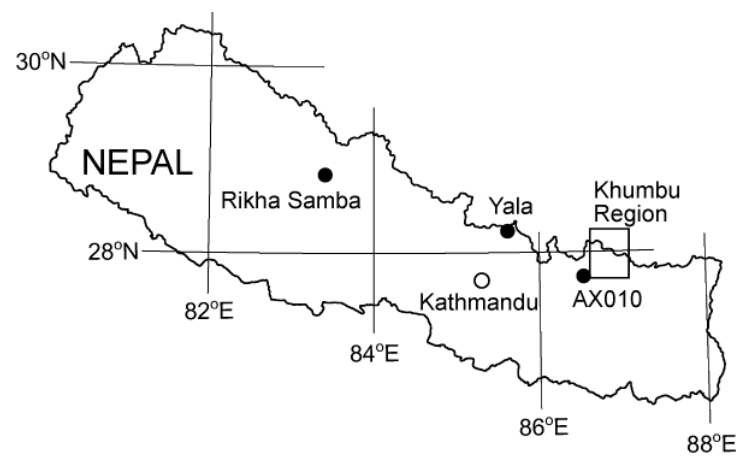

Figure 3. Location map of Glacier AX010, Yala Glacier, Rikha Samba Glacier and Khumbu region.

\section{IMPACTS ON GLACIAL LAKES}

With the accelerated process of glacier retreat, glacial lakes are developing and expanding fast and hence it is important to undertake appropriate pre-emptive action in order to reduce the possibility of a major catastrophic flood. A large flood with ample amount of debris in flood water caused by an outburst of a glacial lake is generally termed as GLOF. Such flood carries the moraine materials from the breach and erodes remarkably both banks of the river, which may causes landslides from the steep sides along the river channel. In the recent history of GLOF in Nepal, the Dig Tsho GLOF on 4 August 1985 was the most devastative one which completely washed away a nearly completed Namche Hydropower plant (with an estimated cost of US \$ 1.5 million), 14 bridges, many houses and trekking trials and cost many lives. This unprecedented degree of damage and property loss attracted the attention of different government and non-government organizations. After the Dig Tsho GLOF the systematic study of glacial lakes in Nepal began at the Water and Energy Commission Secretariat (WECS). At present the DHM, Government of Nepal and International Centre for Integrated Mountain Development (ICIMOD) are carrying out different research activities on glacial lakes together with government and national and international educational institutions in Nepal. Table 1 shows the general features of major six glacial lakes of Nepal.

The Lower Barun Glacial Lake lies at the foot of Mount Makalu in Sankhuwasabha district. The lake was not visible in the topographic map on a scale of 1:63,360 published by Survey of India in 1967 based on the 1963 survey. The map published by Nepal-Kartenwerk der Arbeitsgenmeinschaft für vergleichende Hochgebirgsforschung (Schneider) No.2 on a scale of 1:50,000 in 1965 showed the lake in the form of a supraglacial lake. The supraglacial lake in 1965 has developed to become bigger in size and in the form of an end moraine dammed lake. The Lower Barun Glacial Lake appeared around the mid-1960s and has developed in dimension very rapidly with its area $0.78 \mathrm{~km}^{2}$ in 1997.

The Imja Glacial Lake lies in the Khumbu region, Solukhumbu district. Lhotse Shar, Imja and Ampulapcha are the parent glaciers of Imja Glacial Lake. According to the data from a survey done in April 1992, the length and width of the lake are $1.3 \mathrm{~km}$ and $0.5 \mathrm{~km}$, respectively. The average depth of the lake is $47 \mathrm{~m}$ and the maximum depth is $99 \mathrm{~m}$. The lake occupies an area of $0.60 \mathrm{~km}^{2}$ with stored estimated at about 28 million $\mathrm{m}^{3}$. The lake increased to its length 2.03 $\mathrm{km}$ and area to $0.96 \mathrm{~km}^{2}$ with stored water 35.8 million $\mathrm{m} 3$ as shown in Table 1 in May 2009. 
Dig Tsho Glacial Lake is located in Langmoche Valley in Khumbu region, Solukhumbu district. The lake was breached on 4 August 1985 and emptied the lake water within four to six hours. The flood water surged 10-15 $\mathrm{m}$ high in the valley for more than $90 \mathrm{~km}$ in the form of a huge 'black' mass of debris [8]. [9] estimated that 6-10 million $\mathrm{m}^{3}$ of water drained from Dig Tsho Lake within about four hours, giving an average discharge of $500 \mathrm{~m}^{3} \mathrm{~s}^{-1}$. However, considering the character of the triggering mechanism, it is assumed that the initial peak discharge was probably at least $2,000 \mathrm{~m}^{3} \mathrm{~s}^{-1}$. The lake area in 1974 was around $0.14 \mathrm{~km}^{2}$ whereas in 1992 it was $0.43 \mathrm{~km}^{2}$.

Tam Pokhari (Sabai Tsho) is a moraine-dammed glacial lake situated at an elevation of 4432 $\mathrm{m}$ asl at the headwaters of the Inkhu Khola, one of the tributaries of the Dudh Koshi River in Khumbu region. The dimensions of the lake in 1963 were $515 \mathrm{~m}$ long and $270 \mathrm{~m}$ wide with an area of about $0.138 \mathrm{sq} . \mathrm{km}$. The lake area increased to $0.472 \mathrm{sq} . \mathrm{km}$ with a length of 1150 $\mathrm{m}$ in 1992, measured on the topographic map published in 1996 based on the aerial photographs of 1992 and the satellite images of 1992 and 1993. Tam Pokhari Glacial Lake is formed at the tongue of the Sha (Sabai) Glacier. The volume of water released due to the lake burst on 3 September 1998 was 17 million $\mathrm{m}^{3}$ by a breach $42 \mathrm{~m}$ deep [10]. Two persons were killed, four suspension bridges and two wooden bridges were damaged, and farmlands were buried.

Tsho Rolpa Glacial Lake is situated in the Rolwaling Valley, in the Tama Koshi River Basin in Dolakha District. It is at an elevation of $4,580 \mathrm{~m}$ asl and it lies at $27^{\circ} 50^{\prime} \mathrm{N}$ latitude and $86^{\circ}$ $28^{\prime}$ E longitude. The lake is located at the foot of the Gauri Shankar Range, south of the Tibet (China) border. Tsho Rolpa Glacial Lake is east-west elongated and is located at the tongue of the Trakarding Glacier in the Rolwaling Valley. Tsho Rolpa Glacial Lake has developed from $0.23 \mathrm{~km}^{2}$ in 1959 to $1.55 \mathrm{sq} . \mathrm{km}$ in 1999 . Then the lake water level was lowered by $3 \mathrm{~m}$ in 2000 and its area increased surprisingly to $1.76 \mathrm{~km}^{2}$ in 2002 . The most recent study on this glacial lake in May 2009 showed its area $1.54 \mathrm{~km}^{2}$, length $3.45 \mathrm{~km}$ and stored water volume 85.94 million $\mathrm{m}^{3}$.

Thulagi Glacial Lake lies at an elevation of 4,146 $\mathrm{m}$ asl to the southwest of Mount Manasalu in the headwaters of the Dona Khola, a tributary of the Marsyangdi River in west Nepal. The volume of this lake is increasing due to the fast retreat of Thulagi Glacier. The lake surface area has been increased from $0.22 \mathrm{~km}^{2}$ in 1960 to $0.76 \mathrm{~km}^{2}$ in 1995 and the corresponding length of lake from $0.6 \mathrm{~km}$ to $1.97 \mathrm{~km}$, but the width of lake is not changed much. Based on the field survey in July 2009 the lake area was $0.94 \mathrm{~km}^{2}$, length $2.54 \mathrm{~km}$ and stored water was 35.3 million $\mathrm{m}^{3}$. 
Linnaeus ECO-TECH '10

Kalmar, Sweden, November 22-24, 2010

Table 1. Outline of the studied glacial lakes of Nepal

\begin{tabular}{|c|c|c|c|c|c|c|}
\hline & $\begin{array}{l}\text { Lower } \\
\text { Barun }\end{array}$ & Imja & Dig Tsho & Tam Pokhari & Tsho Rolpa & Thulagi \\
\hline Latitude & $\begin{array}{ll}27^{\circ} & 48^{\prime} \\
\mathrm{N} & \end{array}$ & $\begin{array}{ll}27^{\circ} & 59^{\prime} \\
\mathrm{N} & \end{array}$ & $\begin{array}{ll}27^{\circ} & 52^{\prime} \\
\mathrm{N} & \end{array}$ & $27^{\circ} 44^{\prime} \mathrm{N}$ & $27^{\circ} 50^{\prime} \mathrm{N}$ & $\begin{array}{ll}28^{\circ} & 30^{\prime} \\
\mathrm{N} & \end{array}$ \\
\hline Longitude & $\begin{array}{l}87^{\circ} \quad 07^{\prime} \\
\mathrm{E}\end{array}$ & $\begin{array}{l}86^{\circ} 56^{\prime} \\
E\end{array}$ & $\begin{array}{l}86^{\circ} 35^{\prime} \\
E\end{array}$ & $86^{\circ} 15^{\prime} \mathrm{E}$ & $86^{\circ} 28^{\prime} \mathrm{E}$ & $\begin{array}{l}84^{\circ} 28^{\prime} \\
\mathrm{E}\end{array}$ \\
\hline $\begin{array}{l}\text { Altitude } \\
(\mathrm{m} \text { asl }))\end{array}$ & 4570 & 5010 & 4365 & 4432 & 4580 & $\sim 4081$ \\
\hline Depth (m) & & & & 45 & & \\
\hline Average & 50 & 41.6 & 20 & Left after & 55.1 & 41.8 \\
\hline Maximum & 118 & 96.5 & & GLOF & 133.5 & 80 \\
\hline Length $(\mathrm{km})$ & 1.250 & 2.03 & 1.24 & 1.15 & 3.452 & 2.538 \\
\hline Width $(\mathrm{km})$ & 0.625 & 0.53 & 0.44 & 0.5 & 0.5 & 0.45 \\
\hline Area $\left(\mathrm{km}^{2}\right)$ & 0.78 & 0.9596 & 0.356 & 0.47 & 1.452 & 0.9629 \\
\hline $\begin{array}{l}\text { Stored water } \\
\left(10^{6} \mathrm{~m}^{3}\right)\end{array}$ & 28 & 35.8 & 10 & 21.25 & 76.6 & 31.8 \\
\hline $\begin{array}{l}\text { Drainage area } \\
\left(\mathrm{km}^{2}\right)\end{array}$ & 50 & NA & NA & NA & 77.6 & 55.4 \\
\hline $\begin{array}{l}\text { Approximate } \\
\text { age (years) }\end{array}$ & 40 & 50 & 55 & $50+$ & 55 & 55 \\
\hline $\begin{array}{l}\text { GLOF release } \\
\left(10^{6} \mathrm{~m}^{3}\right)\end{array}$ & NA & NA & 8 & 17 & NA & NA \\
\hline $\begin{array}{l}\text { Data obtained } \\
\text { in }\end{array}$ & 1997 & $\begin{array}{l}\text { May } \\
2009\end{array}$ & 2005 & Sept. 1999 & Aug. 2009 & $\begin{array}{l}\text { July } \\
2009\end{array}$ \\
\hline
\end{tabular}

(from ICIMOD, 2001 and updated) 
Linnaeus ECO-TECH '10

Kalmar, Sweden, November 22-24, 2010

\section{ADAPTATION INITIATIVES}

Folowing two activities were carried out on Tsho Rolpa Glacial Lake for adaptation measures to overcome the impacts of climate change in the cryospheric sector in the Nepalese Himalayas.

\subsection{Test Siphon}

A test siphon system at the lake was provided by the Wavin Overseas Company of the Netherlands through the efforts of the Netherlands-Nepal Association of Amsterdam. The system was installed at the site successfully in 1995 to test the materials and design mechanisms. However, due to regular need of maintenance and lack of enough space for pipes, the siphon method was not a success. That was followed by assurance from the Netherlands Government of financial support for mitigation work at the lake.

\subsection{Establishment of Early Warning System (EWS)}

Following panic created by the media in the summer of 1997 in the Rolwaling and Tama Koshi Valleys, the GoN implemented an early warning system at the end of June 1997 to provide timely warning to the people. An Army camp was established on the lake side at the village of Naa, approx. $3 \mathrm{~km}$ downstream from the lake. A police post was also established at Naa and another police post was established at Beding, approx. $9 \mathrm{~km}$ downstream from the lake. Each of the army and police posts were provided with a HF radio transceiver and the army post at Naa had a back-up set. In addition the two army posts were provided with satellite telephones. The army post at the lakeside used one of the phones to contact the disaster prevention cell at the Home Ministry twice a day to deliver a status report. In the event of GLOF, Radio Nepal, the national broadcaster, would broadcast a warning.

The first flood warning system was installed in May 1998 to warn the people living downstream from Tsho Rolpa Glacial Lake, in the potential GLOF hit area along the Rolwaling and Tama Koshi valleys as well as at the Khimti Hydroelectric Project [11]. The DHM implemented the project and the technical design of the system was by BC Hydro International Limited. It was financed by the World Bank. The GLOF sensing system consists of six sensors with three connected each of the two remote stations with meteor burst and extended line of sight capability. It consists of 19 warning stations, located at 17 villages along Rolwaling and Tama Koshi Valleys. The automated sirens will warn the villages in case of a GLOF from Tsho Rolpa Glacial Lake. However, the EWS is not in working condition at present due to damage to automated siren. Community involvement is a must in such installment of equipments.

\section{MITIGATION INITIATIVES ON TSHO ROLPA GLACIAL LAKE}

Tsho Rolpa is the only glacial lake where detailed study and mitigation measures to reduce impacts of climate change had been undertaken in Nepal. The Government of Nepal (GoN) had implemented an early warning system at the lake and identified the area of a potential GLOF hit downstream. A detailed multidisciplinary study on the stability of the moraine dam was conducted and the appropriate method for lowering the lake was chosen. The excavation of an open cut channel in the end moraine dam was carried out. For the mitigation work at Tsho Rolpa Glacial Lake, the major funding was from the Netherlands Government with 
some contribution from the GoN. All the construction work of the first phase mitigation work was completed by the end of June 2000 . After the mitigation works $15 \mathrm{Kw}$ hydroelectricity was generated from the water flowing down from the canal.

\section{CONCLUSIONS}

The ongoing climatic changes clearly showed that Nepalese glaciers are shrinking and glacial lakes are getting bigger and bigger. The surface of Khumbu Glacier lowered by $10 \mathrm{~m}$ throughout the debris-covered ablation area in the period during 1978 to 1995 . The terminus retreat rates of Glacier AX010 in the Shorong Himal from 1989 to 1995, 1996 to 1999 and 1999 to 2004 were $-6.7 \mathrm{~m} \mathrm{a}^{-1},-30 \mathrm{~m} \mathrm{a}^{-1}$ and $-14 \mathrm{~m} \mathrm{a}^{-1}$, respectively. The terminus of Yala Glacier in the Langtang Valley was retreated by 3 to $4 \mathrm{~m} \mathrm{a}^{-1}$ between 1987 and 1996. Similarly, Rikha Samba Glacier in the Hidden Valley in the western Nepal was retreated $10 \mathrm{~m}$ $\mathrm{a}^{-1}$ between 1974 and 1994. Also the ELAs shifted up between the end of the LIA and 1992 and between 1959 and 1992 in eastern Nepal by 79 and 25 m, respectively.

The ongoing rapid retreat of glaciers is leading to expansion of existing glacial lakes with increasing risk of GLOF events. Imja Glacial Lake occupies an area of $0.60 \mathrm{~km}^{2}$ with stored water estimated at about 28 million $\mathrm{m}^{3}$ in 1992 which was increased to area $0.96 \mathrm{~km}^{2}$ with stored water 35.8 million $\mathrm{m}^{3}$ in May 2009. The area of Tsho Rolpa Glacial Lake in Dolakha district was expanded to $1.452 \mathrm{~km}^{2}$ in August 2009 from $0.23 \mathrm{~km}^{2}$ in 1959 . Similarly, the surface area of Thulagi Glacial Lake has been increased from $0.22 \mathrm{~km}^{2}$ in 1960 to $0.76 \mathrm{~km}^{2}$ in 1995 and the corresponding length of lake from $0.6 \mathrm{~km}$ to $1.97 \mathrm{~km}$. Based on the field survey in July 2009 the lake area was $0.94 \mathrm{~km}^{2}$, length $2.54 \mathrm{~km}$ and stored water was 35.3 million $\mathrm{m}^{3}$. These expanding glacial lakes are holding huge amount of water within the moraine dam among which considerable amount of water may be released suddenly if the dam breaks causing flood and debris flow with high chances of huge loss of life, infrastructure and biodiversity of the region and downstream. Some adaptation and mitigation measures applied only in Tsho Rolpa Glacial Lake but not in other glacial lakes. Also detail study of other big glacial lakes did not carried out yet in the Nepalese Himalayas. Therefore, more studies on glaciers and glacial lakes are very essential together with some preventive measures to reduce the risk of GLOF hazards in the Himalayas.

\section{REFERENCES}

[1] Cook, E. R., J. K. Paul and D. J. Philip, 2003. Dendroclimatic signals in long tree-ring chronologies from the Himalayas of Nepal. Int. J. Climatol., 23, 707-732.

[2] Shrestha, A. B., C. P. Wake, P. A. Mayeski and J. E. Dibb, 1999. Maximum temperature trends in the Himalaya and its vicinity: an analysis based on temperature records from Nepal for the

period 1971-94. J. Climate, 12, 2775-2786.

[3] Barry, R. G., Chorley, R. J., 1987. Atmosphere, Weather and Climate $5^{\text {th }}$ Edition, Associated Book Publishers (UK) Ltd., 441.

[4] ICIMOD/UNEP, 2001. Inventory of Glaciers, Glacial Lakes and Glacial Lake Outburst Floods, Nepal

[5] Kadota, T., Seko, K., Aoki, T., Iwata, S., Yamaguchi, S., 2000. Shrinkage of the Khumbu Glacier, east Nepal from 1978 to 1995, Nakawo, Raymond, Fountain (Ed) Debris-Covered Glaciers, IAHS Publication no. 262, pp. 235-243. 
[6] Yamada, T., 1992. Report for the First Research Expedition to Imja Glacier Lake - 25 March to 12 April 1992, WECS Report No. 3/4/120892/1/1, Seq. No. 412. Kathmandu, Nepal: WECS/JICA.

[7] Kayastha, R. B. and Harrison, S. P., 2008. Changes of the equilibrium line altitude since the Little Ice Age in the Nepalese Himalayas. Annals of Glaciology, Vol. 48, 93 99.

[8] Galey, V. J., 1985. Glacier Lake Outburst Flood on the Bhote/Dudh Kosi, August 4, 1985, WECS internal report. Kathmandu: WECS.

[9] Vuichard, D.; Zimmerman, M., 1987. 'The 1985 catastrophic drainage of a morainedammed lake, Khumbu Himal, Nepal: Cause and consequence'. In Mountain Research and Development, 7(2): 91-110.

[10] Dwivedi, S. K.; Acharya, M. D.; Joshi, S. P., 1999. 'Preliminary Report on the Tam Pokhari GLOF of 3rd September 1998'. In WECS Bulletin, 10(1): 11-13.

[11] BC Hydro, 1998. Final Project Completion Report. Tsho Rolpa GLOF Warning System Project. 